\title{
Ecological studies on fish fauna associated with Macrocystis pyrifera belts in the south of Fueguian Islands, Chile
}

\author{
Carlos A. Moreno and H. Fernando Jara* \\ Instituto de Ecología y Evolución, Universidad Austral de Chile, Casilla 567, Valdivia, Chile
}

\begin{abstract}
Fish fauna, habitat characteristics, and trophic relations within a Macrocystis pyrifera kelp community were studied in fjords and channels in the south of Tierra del Fuego, Chile between 1979 and 1980. The ichthyofauna is very similar to that described for the subantarctic islands, especially because of the predominance of nototheniid species. Greater species richness was found associated with rocky substrates. Experimental modifications of kelp canopy affected the abundance of only 3 out of 18 fish species. No fish were found to be herbivorous or to prey on sea urchins, but their diet was dominated by detritivores (amphipods and isopods) associated with the kelp. Comparison of these organizational features with those in kelp communities of the northern hemisphere illustrates notable contrasts. In spite of these differences, the trophic position of fish is similar within a recycling food web. These Tierra del Fuego fish assemblages also appear to optimize microhabitat utilization in the rocky substrate, as has been documented in the North Pacific Ocean.
\end{abstract}

\section{INTRODUCTION}

Extensive belts of macro-algae exist along many coasts around the world. Perhaps the most conspicuous are those formed by the giant kelp Macrocystis pyrifera, whose geographical distribution in the Pacific Ocean includes the west coast of North America and southern Chile (Neushul, 1971). Ecological research in these kelp belt communities has been focused mainly on 3 aspects: (1) functional relations between macroalgae and their direct consumers (e.g. Foster, 1975a; Foreman, 1977; Pearse and Hines, 1979; Castilla and Moreno, 1982); (2) relations and impacts that predators impose on herbivores and, hence, on community structure (e.g. Mann and Breen, 1971; Estes and Palmisano, 1974; Estes et al., 1978; Simenstad et al., 1978; Duggins, 1980); or, (3) interactions among algae (e.g. Dayton, 1975; Foster, 1975b; Pearse and Hines, 1979; Moreno and Sutherland, 1982; Santelices and Ojeda, 1983). Little is known, however, about the fish fauna that utilizes kelp belts as habitat and is linked trophically to the recycling chain originating from algal detritus.

\footnotetext{
- Present address: Department of Biology, San Diego State University, San Diego, California 92182-0057, USA
}

Macrocystis pyrifera belts in California host a rich fish fauna of more than 125 species (Ebeling et al., 1980). In addition to planktivorous fishes (Hobson and Chess, 1976; Ebeling et al., 1980), there are herbivorous fishes capable of exerting detrimental effects on algae (North, 1979). However, the main and more diverse group of species is associated with more stable and heterogeneous benthic habitats which provide abundant invertebrates as food (Quast, 1968; Simenstad et al., 1978; Ebeling et al., 1980).

In Chile, on the other hand, the situation is poorly understood. Moreno et al. (1979) reported an increase in the diversity of littoral fish towards the north, resulting from the addition of either herbivorous fish or species (Labridae) capable of feeding on sea urchins and limpets. Macrocystis pyrifera belts, however, dominate the extensive system of fjords and channels of the Chilean coast in the south of Isla de Chiloé (Dayton, 1974). In these areas, the ichthyofauna is largely dominated by species of Nototheniidae or 'tramas' (Navarro and Pequeño, 1978), but there is no information on the fish-kelp belt community relations from such a prominent community along the southern Chilean coast.

Based on underwater observations and long-term field experiments, the present study provides original 
insights into relations among the fish fauna, habitat characteristics, and food webs within Macrocystis pyrifera communities of southern Chile. In addition, the similarities between this and other, comparable, communities described from the northern hemisphere are discussed.

\section{MATERIALS AND METHODS}

\section{Study site}

The study was carried out in the vicinity of Puerto Toro, Isla Navarino, in waters of the Paso Picton (55 $04^{\prime} \mathrm{S} ; 67^{\circ} 04^{\prime} \mathrm{W}$ ) (Fig. 1). The area was visited seasonally for periods of 2 wk from November 1979 to July 1980. For all experiments reported here sampling and observations were made during the following periods: November 2-18, 1979; January 12-30, 1980; May 10-25, 1980; and July 10-25, 1980.

At the location in question, Macrocystis pyrifera extends as narrow coastal belts 50 to $100 \mathrm{~m}$ wide surrounding the sheltered and semi-sheltered sides of the

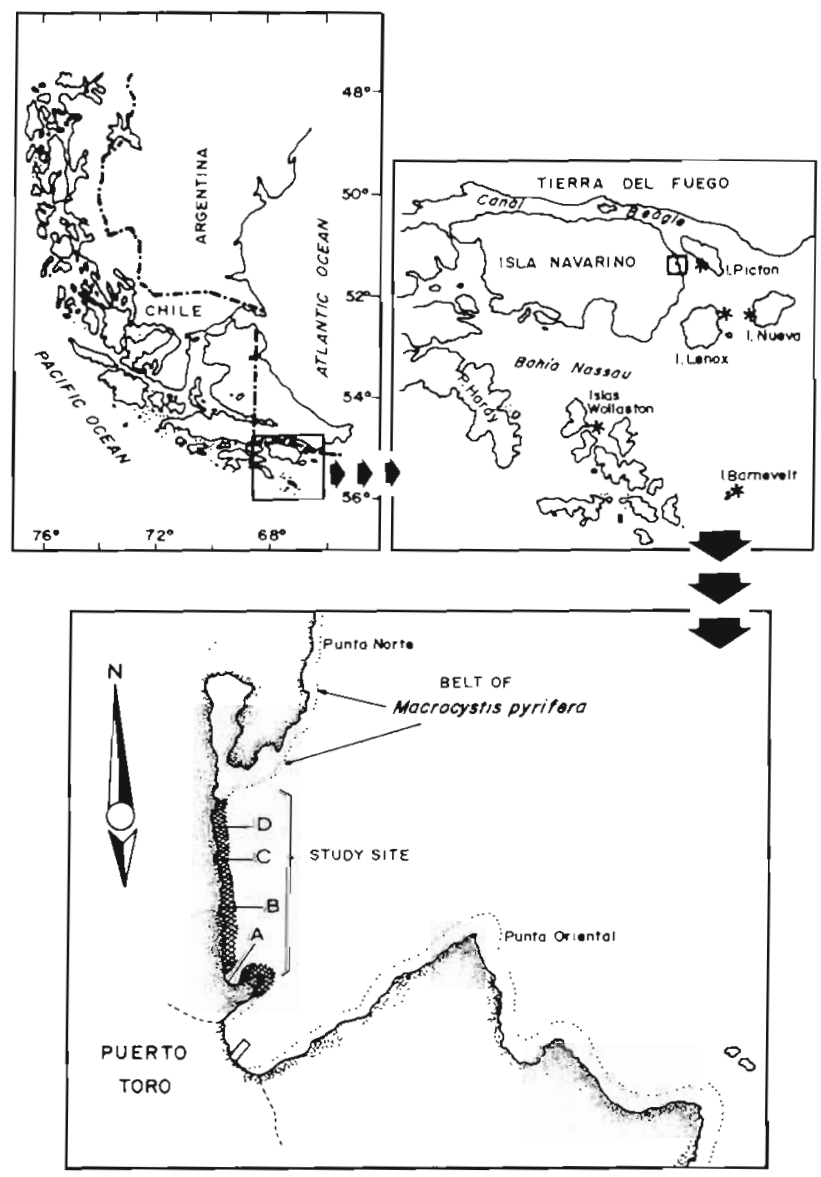

Fig. 1. Beagle Channel area showing location of study sites $(A, B, C, D)$ at Puerto Toro and neighboring islands (") island. Kelp belts normally begin 1 to $2 \mathrm{~m}$ below the limit of spring tides and extend down to 10 to $15 \mathrm{~m}$ depth. Within the belts, rectangular and pyramidal rocks create a heterogeneous relief with numerous crevices and caves. The characteristics of the sea floor change with depth, and the end of the rocky substrate also marks the disappearance of $M$. pyrifera, giving way to sandy bottoms. Continuity of the kelp around protected shores of the island is interrupted only by small coves where sandy bottom predominates. Water temperatures range between 5 and $6{ }^{\circ} \mathrm{C}$ in winter (July-August) and from 8 to $9{ }^{\circ} \mathrm{C}$ in summer (January-April) (Santelices and Ojeda, 1983). Pickard (1971) reported on the oceanographic conditions of the area; more detailed descriptions of this site have been given by Castilla and Moreno (1982) and Santelices and Ojeda (1983).

To obtain comparative observations of fish abundance, other sites with similar characteristics at 5 neighboring islands were also visited during May 1980 (Fig. 1).

\section{Sampling methods}

Quantitative estimates of fish abundance were obtained by using a $3 \mathrm{~m}$ high and $40 \mathrm{~m}$ long gill net set overnight on the bottom, perpendicular to the coast line. The stretched mesh size was graded from $20 \mathrm{~mm}$ at one end to $70 \mathrm{~mm}$ at the other end of the net. By using this net and method of deployment we attempted to (1) avoid net selectivity due to aperture size, and (2) improve capture rates of juveniles and small forms near the shore side of the belt.

In addition, numerous specimens were collected and quantitative observations were carried out during a total of 240 h of SCUBA diving, distributed throughout the year. During summer and winter 1980, vertical transects were performed along Macrocystis plants located at the outer border of the kelp belt (10 to $12 \mathrm{~m}$ deep). All the fish species resting or sheltered among these plants were identified and counted. For further analysis, data were grouped in terms of frequency of occurrence in holdfast, stipe, and canopy of the plant. For practical purposes definitions are as follows: holdfast - the whole hapteral complex from the rock surface to the sporophylls; stipe - the part of the plant almost devoid of blades from the holdfast up to one meter under the surface; canopy - the densest portion of the plant extending at the surface.

Total length (TL) was measured to the nearest mm for all fish captured; their stomachs were injected with $4 \%$ formalin for further analysis. In the laboratory, stomach contents were sorted, identified to the lowest taxon feasible, and the frequency of occurrence of each food item recorded (Windell, 1971). Levels of similarity 
among diets of the various species were calculated using Morisita's (1959) index, $\mathrm{C}_{\lambda}$, and illustrated using dendrograms according to the linkage method of Sokal and Sneath (1963)

To measure the influence of bottom spatial complexity on fish species richness, sandy (Fig. 2A) as well as rocky (Fig. 2C) bottom habitats were investigated. Two

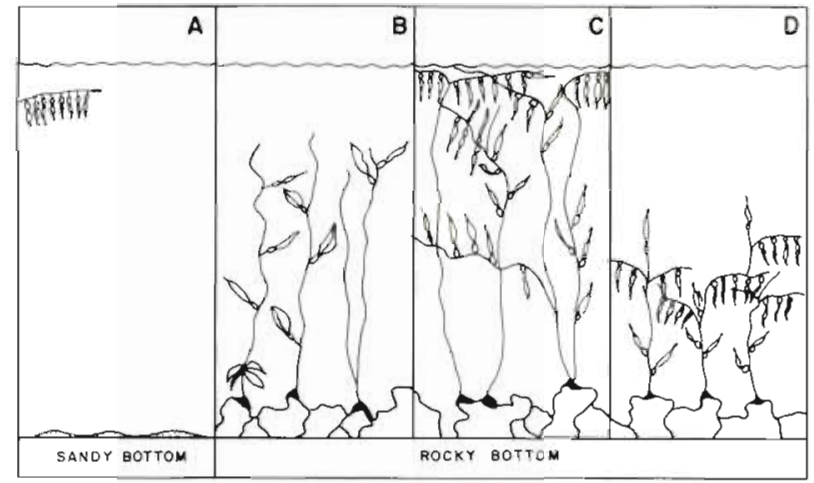

Fig. 2. Experimental design and canopy manipulations in a Macrocystis pyrifera belt at Puerto Toro, Isla Navarino. (A) Sandy bottoms near the kelp belt; (B) canopy harvesting $1 \mathrm{~m}$ below the surface; (C) control area; (D) mid-water canopy

experiments were carried out to ascertain the role of Macrocystis pyrifera as a habitat for fish. The first consisted of kelp canopy harvesting, about $1 \mathrm{~m}$ below the surface in a $10 \mathrm{~m}$ wide and $50 \mathrm{~m}$ long area perpendicular to the coast line (Fig. 2B). Harvesting of the canopy was repeated every season, and during the following 3 to $6 \mathrm{~d}$ the area was sampled with the gill net. The second experiment consisted of promoting the development of a midwater kelp canopy (Fig. 2D). In spring 1979, all kelp plants in a $10 \mathrm{~m}$ wide and $40 \mathrm{~m}$ long area perpendicular to the shore were cut ca. $1 \mathrm{~m}$ above their holdfasts. Further $M$. pyrifera recruitment and growth occurred, and by January 1980 the kelp had developed a canopy between 3 and $4 \mathrm{~m}$ over the bottom; in this stage the area was sampled for the first time. Sampling was repeated before the canopy attained full development, during the subsequent 2 growth seasons (early May and late July, 1980).

For each sampling or manipulative experiment described above (Fig. 2A, B, C, D), a total of 4 gillnet collections were obtained between summer and winter 1980. Thus, collections for each treatment were assigned numbers from 1 to 16 as follows: $A=13$ to 16 ; $\mathrm{B}=5$ to $8 ; \mathrm{C}=1$ to $4 ; \mathrm{D}=9$ to 12 . After verification of normality and homogeneity of variances (Sokal and Rohlf, 1969), fish catches from 4 collections in each treatment were further pooled and compared to the control habitat (Fig. 2C) using the Student's t-test.

In evaluating the relationship between detached algae and fish diversity, semi-quantitative estimates were made with respect to the amount of drifting algal material deposited on the bottom, according to 5 levels of abundance: (1) absent; (2) very rare; (3) scarce; (4) abundant; (5) very abundant. For the purpose of this analysis, species of fish inhabiting the upper levels of the algal belt were not included. Comparisons were made among the Puerto Toro site and the neighboring island locations for May 1980. Localities considered were similar in abundance and distribution of $\mathrm{MaC}-$ rocystis plants, as well as in slope and bottom characteristics (Santelices, 1981).

\section{RESULTS}

\section{Ichthyological observations}

During the present study 18 species of small fish were collected, half of these being nototheniids (Table 1). Nototheniids are widely distributed around Antarctica, so that many authors have suggested an Antarctic origin for this taxon (e.g. De Witt, 1971; Andersen and Hureau, 1979).

The remainder of the species collected are also typical of the southern hemisphere, none of them having a bipolar distribution. The geographical range of this species group reaches its northern limit near Isla Grande de Chiloé (Fowler, 1941; Navarro and Pequeño, 1978). The only new taxonomic record based on these collections was the rediscovery of Patagonotothen trigramma (Regan) (Moreno and Jara, 1981).

\section{Spatial distribution}

Most of the species recorded have demersal habits, the exception being Patagonotothen tessellata (Richardson) and Champsocephalus esox (Gunther). The former, distributed throughout the water column, occurs in schools along the periphery of the kelp belt and in open areas within it, but is rarely seen within the kelp belt itself. The latter, a solitary predator remaining almost immobile during the day, actively searches for prey within the kelp belt after dusk.

Two species occupy an intermediate habitat within the kelp belt: Notothenia (Paranotothenia) magellanica Foster is found within the belt, often on kelp laminae and stipes, but frequently visits the intertidal zone with the rising tides; Patagonotothen sima (Richardson) occurs among or rests on Macrocystis fronds most of the year. These fish swim around kelp plants, but if disturbed rapidly seek shelter among the fronds.

The remaining fish are all demersal or epibenthic, a characteristic shared by most of the Nototheniidae (Eastman and DeVries, 1982). 
Table 1. Species composition and size range $(\mathrm{TL} \mathrm{cm})$ of fishes collected in the belt of giant kelp Macrocystis pyrifera, Puerto Toro, Isla Navarino, Chile. Family after Nelson (1976)

\begin{tabular}{|c|c|c|c|}
\hline Species & Family & Total catch & $\begin{array}{c}\text { Size range } \\
(\mathrm{TL}, \mathrm{cm})\end{array}$ \\
\hline Notothenia (P.) magellanica Foster & Nototheniidae & 110 & $3.0-24.0$ \\
\hline Patagonotothen tessellata (Richardson) & Nototheniidae & 78 & $2.0-21.0$ \\
\hline P. longipes (Steindachner) & Nototheniidae & 35 & $15.0-26.0$ \\
\hline P. brevicauda (Lonnberg) & Nototheniidae & 96 & $2.5-22.0$ \\
\hline P. cornucola (Richardson) & Nototheniidae & 60 & $2.8-10.5$ \\
\hline P. sima (Richardson) & Nototheniidae & 40 & $3.0-5.5$ \\
\hline P. trigramma (Regan) & Nototheniidae & 4 & $15.9-20.1$ \\
\hline Eleginops maclovinus (Valenciennes) & Nototheniidae & 5 & $30.0-32.0$ \\
\hline Harpagifer bispinis (Bloch-Schneider) & Nototheniidae & 59 & $2.5-7.5$ \\
\hline Champsocephalus esox (Gunther) & Channichthydae & 10 & $11.0-33.0$ \\
\hline Cottoperca gobio (Gunther) & Bovichthyidae & 12 & $14.5-26.0$ \\
\hline Agonopsis chiloensis (Jenyns) & Agonidae & 5 & $4.0-5.5$ \\
\hline Leptonotus blainvillianus (Eydoux \& Gervais) & Syngnathidae & 3 & $7.0-20.0$ \\
\hline Aplochiton taeniatus Jenyns & Aplochitonidae & 6 & $10.0-11.5$ \\
\hline Austromenidia nigricans (Richardson) & Atherinidae & 4 & $16.0-18.0$ \\
\hline Salilota australis (Gunther) & Gadidae & 2 & $3.5-6.0$ \\
\hline Austrolycus depressiceps Regan & Zoarcidae & 12 & $5.0-36.0$ \\
\hline Careproctus crassus De Buen & Cyclopteridae & 2 & $4.5-5.0$ \\
\hline Total & & 543 & \\
\hline
\end{tabular}

Two notable seasonal changes affecting the spatial distribution and abundance patterns of these populations were observed. The first consisted of the emigration of Notothenia (P.) magellanica from the kelp belt by early winter (June-July). Those that left the kelp belt were reddish in coloration and relatively large individuals (Fig. 3), both features attributed to sexual maturity (Hureau, 1970).

The second important change was the migration of

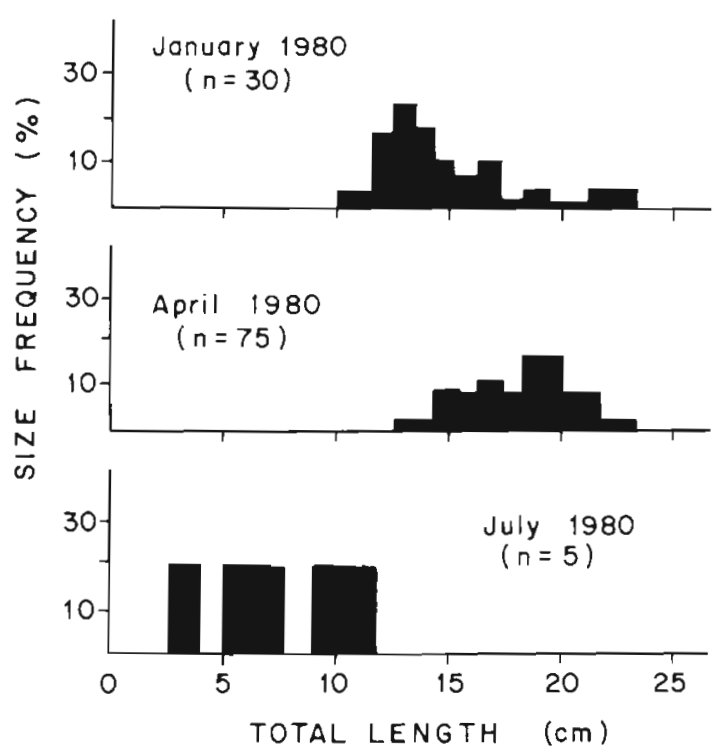

Fig. 3. Demographic representation of Notothenia (P.) magellanica population in a Macrocystis pyrifera belt at Puerto Toro, Isla Navarino
Table 2. Spatial distribution of Patagonotothen sima in giant kelp Macrocystis pyrifera, Canal Picton, Isla Navarino, Chile

\begin{tabular}{|lcr|}
\hline Microhabitat & $\begin{array}{c}\text { January } 1980 \\
\text { Frequency } \\
(\%)\end{array}$ & $\begin{array}{c}\text { July } 1980 \\
\text { Frequency } \\
(\%)\end{array}$ \\
\hline Fronds (1 to $2 \mathrm{~m})$ & $12(70.6)$ & $0(0)$ \\
Stipes (3 to $8 \mathrm{~m})$ & $5(29.4)$ & $4(22.2)$ \\
Holdfasts (9 to $10 \mathrm{~m})$ & $0(0)$ & $14(77.8)$ \\
\hline
\end{tabular}

Patagonotothen sima from the canopy to the holdfast of Mactocystis plants during its reproductive period in winter (Table 2). These fish lay their egg masses in spaces created within the holdfast; they provide parental care in a way similar to that described for other nototheniids (Daniels, 1978; Moreno, 1980).

\section{Bottom and canopy effects on fish abundance}

Table 3 (Columns $A$ and $C$ ) shows comparative abundance of fishes from a heterogeneous rocky bottom and a homogeneous sandy one. Seven species that occur on the rocky area (control) were absent from the sandy bottom. At the same time, 3 species occurring on the sandy area were absent from the rocky bottom. Only 3 species out of a total of 13 were present in rocky and sandy areas. Patagonotothen cornucola (Richardson) is significantly less abundant (t-test; $P<0.05$ ) in samples from sandy bottom than in the control. $P$. tes- 
Table 3. Comparative abundance of fish under different environmental conditions and experimental manipulations. Mean values $\pm \mathrm{SD}(\mathrm{n}=4)$ of total annual catches, using a gill net in a Macrocystis pyrifera belt at Puerto Toro, Isla Navarino, Chile. (Consult text for experimental conditions $A, B, C, D)$

\begin{tabular}{|c|c|c|c|c|}
\hline Species & $\begin{array}{c}\mathrm{C} \\
\text { Control }\end{array}$ & $\begin{array}{c}\text { A } \\
\text { Sand }\end{array}$ & $\begin{array}{c}\text { B } \\
\text { Canopy } \\
\text { Harvesting }\end{array}$ & $\begin{array}{c}\text { D } \\
\text { Mid-Water } \\
\text { Canopy }\end{array}$ \\
\hline Notothenia magellanica & $8.0 \pm 2.16$ & $3.25 \pm 0.95$ & $0.75 \pm 0.95^{\circ}$ & $7.75 \pm 1.7$ \\
\hline Patagonotothen cormucola & $9.25 \pm 2.5$ & $2.25 \pm 1.25^{\circ}$ & $10.75 \pm 3.3$ & $10.0 \pm 2.94$ \\
\hline P. tessellata & $1.5 \pm 0.6$ & $13.75 \pm 3.77^{\cdots}$ & $10.50 \pm 1.91 \cdots$ & $12.25 \pm 1.50^{\cdots} \cdot$ \\
\hline$P$. longipes & $5.5 \pm 1.7$ & & $5.25 \pm 2.21$ & $2.0 \pm 1.41$ \\
\hline P. brevicauda & $3.0 \pm 2.16$ & & $5.50 \pm 5.06$ & $5.25 \pm 5.43$ \\
\hline P. sima & $4.0 \pm 0.81$ & & $0.25 \pm 0.5^{\cdots}$ & $9.75 \pm 2.5^{\circ}$ \\
\hline P. trigramma & $0.5 \pm 0.57$ & & $0.25 \pm 0.5$ & \\
\hline Champsocephalus esox & $1.5 \pm 0.57$ & & $0.75 \pm 0.5$ & $0.50 \pm 0.57$ \\
\hline Leptonotus blainvillanus & $0.5 \pm 0.57$ & & $0.50 \pm 0.57$ & $0.50 \pm 0.57$ \\
\hline Cottoperca gobio & $0.5 \pm 0.57$ & & $0.50 \pm 0.57$ & $0.75 \pm 0.50$ \\
\hline Eleginops maclovinus & & $0.75 \pm 0.50$ & & \\
\hline Aplochiton taeniatus & & $1.0 \pm 0.81$ & & \\
\hline Agonopsis chiloensis & & $0.25 \pm 0.50$ & & $0.25 \pm 0.50$ \\
\hline
\end{tabular}

sellata, in turn, is by far the most abundant ( $\mathrm{t}$-test; $\mathrm{P}<$ $0.01)$ species on sandy areas.

Within the kelp belt, however, the experimental manipulation of the canopy revealed significant changes for at least 3 species (Table 3; Columns B and D). Notothenia (P.) magellanica and Patagonotothen sima were significantly less abundant (t-test; $\mathrm{P}<0.05$ and $\mathrm{P}<0.01$, respectively) after canopy removal, a result anticipated in the light of our previous observations on the spatial distribution of these species. At the

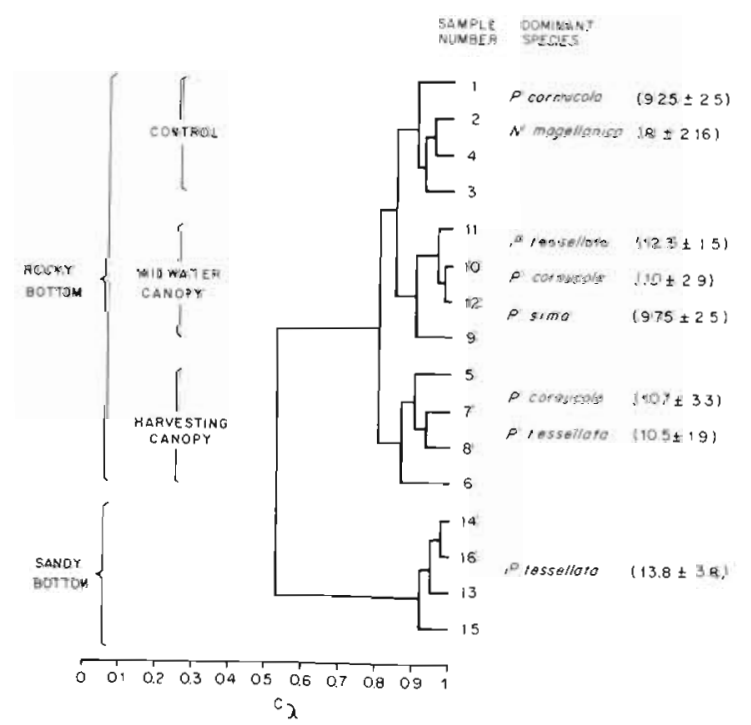

Fig. 4. Similarity (Morisita's $\mathrm{C}_{2}$ ) of fish collections on different bottom types and canopy manipulations from a Macrocystis pyrifera belt at Puerto Toro, Isla Navarino. Mean abundance \pm SD from pooled data for dominant species in each environmental condition is indicated same time, $P$. tessellata increased significantly in abundance whenever more open space was provided either by harvesting the fronds (t-test; $\mathrm{P}<0.01$ ), or by developing a mid-water canopy (t-test; $\mathrm{P}<0.001$ ). When a mid-water canopy was developed, $P$. sima increased significantly (t-test; $\mathrm{P}<0.05$ ) in abundance compared to the control. Interestingly, $N$. (P.) magellanica remained at the same abundance in the control and where a mid-water canopy had developed.

Data listed in Table 3 are summarized in a dendrogram (Fig. 4) which shows clearly that only 4 species characterize each habitat, Patagonotothen cornucola being the numerically dominant species from collections on rocky substrates, while $P$. tessellata is dominant on sandy bottoms. Nevertheless, the latter species always increased its abundance whenever the canopy was altered, suggesting that lack of Macrocystis plants promotes higher abundance of $P$. tessellata on sandy bottoms. $P$. sima depends on the canopy most of the year, except during its reproductive period (June-August), when adults occupy nesting places within the kelp holdfasts. Finally, N. (P.) magellanica characterizes the intermediate zone between the bottom and the canopy, although the absence of a canopy seems to reduce its abundance.

\section{Diet of fish from the Macrocystis belt}

Analyses of the stomach contents of the principal fish species from the Puerto Toro kelp forest revealed similarities among the nototheniids (Fig. 5 and 6). Amphipods dominated most diets while the contribu- 


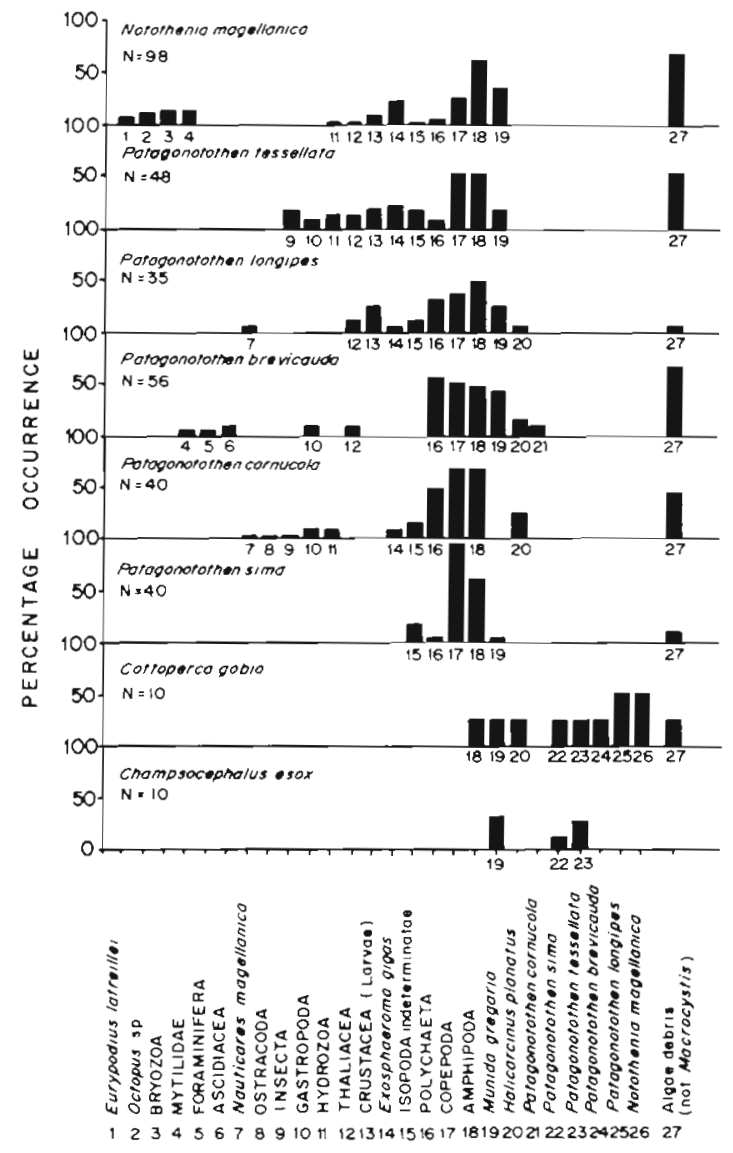

Fig. 5. Frequency of occurrence of 27 prey items in the stomachs of the 8 most common fish species from a Macrocys-

tis pyrifera belt at Puerto Toro, Isla Navarino

tions by other prey taxa depended on the microhabitat used (e.g. bottom, open water, etc.). For example, species occurring in crevices and caves combined their diet of amphipods with polychaetes, as is the case for Patagonotothen cornucola and P. brevicauda (Lonnberg). On the other hand, species living near the surface consumed calanoid copepods and other plank-

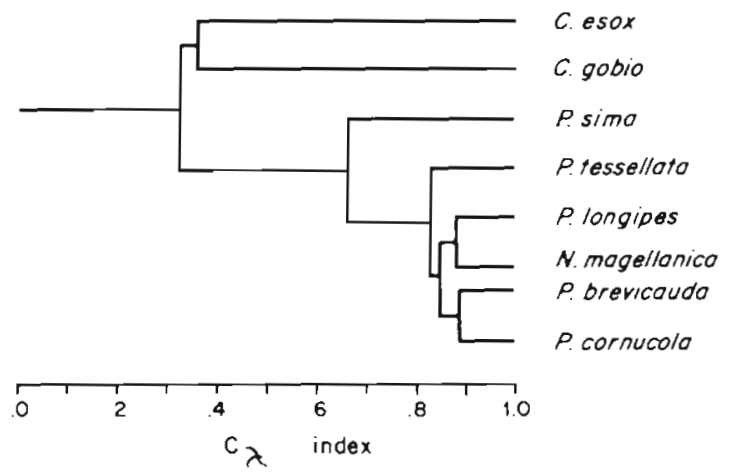

Fig. 6. Similarity (Morisita's $\mathrm{C}_{\lambda}$ ) of diets of the 8 most common fish species from a Macrocystis pyrifera belt at Puerto Toro, Isla Navarino tonic organisms along with the amphipods (e.g. $P$. sima). The ubiquitous isopod Exosphaeroma gigas is important food for species that frequent the intertidal zone (e.g. Notothenia (P.) magellanica, P. tessellata, $P$. cornucola, Harpagifer bispinis). Algal material (mostly filamentous green, brown, and red algae) was consumed by most species; however, Macrocystis pyrifera never appeared in the stomach contents. Nevertheless, the abundance of algal material and amphipods in stomach contents was correlated $(\mathrm{r}=0.72 ; \mathrm{P}<0.05$; $\mathrm{n}=7$ ), suggesting that they are probably consumed simultaneously, as has been shown for Notothenia coriiceps in Antarctica (Moreno and Zamorano, 1980a).

Both Cottoperca gobio (Gunther) and Champsocephalus esox are mainly piscivorous. The former, which rests cryptically on the bottom, feeds mostly on other demersal species (e.g. Patagonotothen cornucola). The latter, which swims freely in mid-water, feeds primarily on $P$. sima and $P$. tessellata. In addition, both species, together with Notothenia (P.) magellanica, consume the anomuran crab Munida subrugosa which is very common within the kelp belt. The relatively large size (average carapace length $35 \mathrm{~mm}$ ) attained by these crustaceans makes them unavailable as food for the smaller-sized species of fish.

\section{Relation between drifting algae and fish species}

Since the abundance of algal remains and amphipods in the stomach contents of fishes from Puerto Toro were correlated, we suspected a relation between the amount of drifting algae (food availabil-

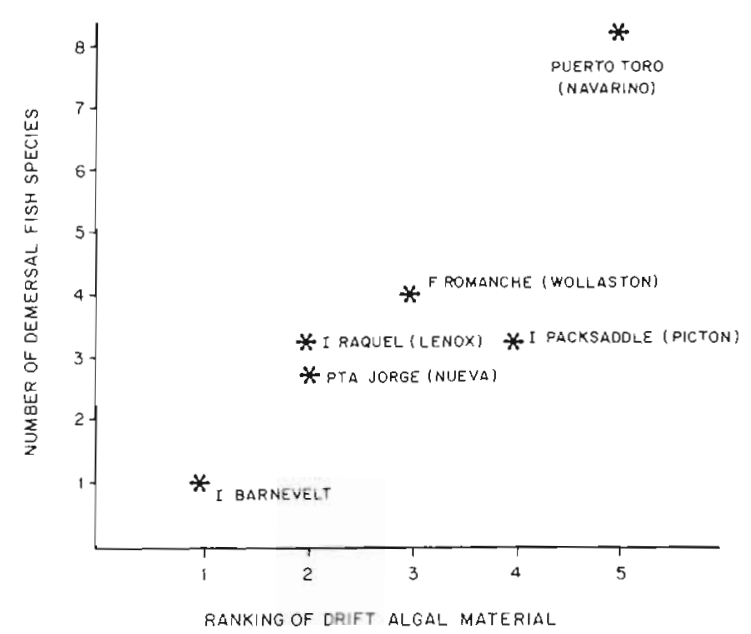

Fig. 7. Relation between number of demersal fish species and rank abundance of drifting algae on the bottom at 6 locations within the southern Chilean archipelago (Isla Navarino-Cabo de Hornos). Names in parentheses: islands where sites are located 
ity) and the amphipods. Fig. 7 supports this assumption indicating that species richness of demersal fish increased whenever the amount of drifting material increased.

\section{DISCUSSION}

Ichthyofauna from the Macrocystis pyrifera belt at Puerto Toro, Isla Navarino, exhibits lower diversity when compared with localities from either northern Chile (Moreno et al., 1979) or with similar kelp belts from California (Quast, 1968; Rosenthal et al., 1974). However, due to biogeographical affinities the results are quite similar to those obtained from subantarctic islands of South Georgia and Kerguelen, which likewise support Macrocystis pyrifera belts dominated by nototheniid and channichthyd fishes (Hureau, 1970; Burchett, 1982; White et al., 1982). Based on the close morphological similarities between hexagrammids ('greenlings') from the North Pacific Ocean and nototheniids ('tramas'), despite their probably unrelated phylogenetic origins, the ichthyofauna from the Aleutian Islands may also be comparable ecologically to the one reported here for the South Fueguian islands. The description by Simenstad et al. (1977) of fish assemblages associated with kelp (Alaria fistulosa) belts at Amchitka Island, fits well to the description of habitat characteristics and niches of fish at Puerto Toro. This is so not only because of the strong morphological similarity between nototheniids and hexagrammids or the presence of snailfish (Cyclopteridae) and poachers (Agonidae) in both systems, but also because both species assemblages are principally demersal, sedentary fish and include few species exploiting habitats near the surface. In this regard, Quast (1968) and Simenstad et al. (1978) agree that bottom relief is the most important factor to be considered when explaining fish diversity and abundance within kelp belts.

In southern Chile, fish do not graze directly on Macrocystis, as they do in California (North, 1979); nor do they prey on sea urchins as some (e.g. Graus nigra and Semicossiphus maculatus) do in central and northern Chile (Moreno et al., 1979; Fuentes, 1981). Algae in stomach contents were closely associated with the occurrence of amphipods, and digestion was not evident. Therefore, the algal remains we found cannot be considered as evidence for herbivory.

The wide spectrum of items in the diet of Notothenia (P.) magellanica contrasted with the rest of the species. This fish ingests most organisms of a size appropriate to enter its mouth; even mussels (Mytilidae) are included. In the Kerguelen Islands, Hureau (1970) found the diet of this fish to consist of gastropods (Nacella [Patinigera] sp.), bivalves (Gaimardia trapezina), and isopods (Exosphaeroma gigas, Serolis sp.), along with decapods, copepods, polychaetes, and algal remains. According to Moreno and Zamorano (1980b) the diets of coastal fish were well correlated with their swimming behaviour. Thus, due to visiting a broad spectrum of habitats, very mobile fish exhibit a wider range of diets than ambush feeders which sit and wait. Clustering of stomach-content data revealed the diets of fish from Puerto Toro to be correlated with the kind of microhabitat occupied within the kelp belt (Fig. 6). In fact, both Patagonotothen brevicauda and $P$. cornucola have similar diets typical of ambush feeders, while the more mobile $N$. (P.) magellanica and $P$. longipes prey on benthic organisms. $P$, tessellata and $P$. sima, on the other hand, reveal their pelagic habits by consuming calanoid copepods. The piscivorous Cottoperca gobio and Champsocephalus esox, in turn, are separated from the rest and also from each other.

Our results from sandy and rocky bottoms at Puerto Toro support the hypothesis that species richness or species diversity depends almost exclusively on bottom relief (Quast, 1968; Rosenthal et al., 1974; Simenstad et al., 1977). Since the higher the bottom heterogeneity, the greater the chances of finding a refuge, heterogeneous substrates should act as buffers against detrimental effects of predation pressures. Long-term consequences of selective forces (e.g. predation, competition) would imply the evolution of morphological diversity through niche partitioning to maximize bottom (habitat) utilization. In the short-term, predation can also alter the patterns of fish spatial distribution and habitat 'specialization', as was observed in Bahía de Corral after a sea lion (Otaria flavescens) colony was eliminated (Moreno, 1981). Accordingly, predation could also be controlling local fish diversity at Puerto Toro. The fur seal Arctocephalus gazella, the blue eyed shag Phalacrocorax atriceps, and the magellanic penguin Spheniscus magellanicus are all piscivorous predators (Boswall and MacIver, 1975; Schlatter and Moreno, 1976; Venegas and Jory, 1979) that frequent the area. Our experiments indicate that only species that either swim near the surface or use upper and mid-water fronds were affected when the canopy was manipulated. On the other hand, observational evidence suggests that the more heterogeneous the bottom and the greater the amount of accumulated drifting algae, the higher the abundance of demersal fish. Two aspects worth considering separately are implicitly mixed in the above statement: fish abundance and fish species richness. Fish abundance, according to our data on stomach content analyses, could be linked to the carrying capacity of the food web developed from algal detritus and its consumers, i.e. amphipods and isopods. These prey, in turn, play a key role as recycling agents. 
Therefore, the relation among greater amounts of drifting algal material, higher abundances of detritivorous crustaceans, and greater abundances of fish could be explained in terms of a larger amount of primary production cycled and made available to fish by the detritivorous fauna. However, care must be taken in interpreting this relation (Fig. 7) since the occurrence of both events is probably the result of a third factor, namely the increase of bottom heterogeneity. Therefore, the more heterogeneous the bottom the greater the amount of drifting algae retained and, coincidentally, the higher the probabilities for fish to find refuges from predators (fur seal, cormorants, fish, etc.).

Thus, the propositions made by Quast (1968) and Simenstad et al. (1978) agree well with the dynamics exhibited by the system at Puerto Toro. Here, highly heterogeneous substrates offer more antipredatory refuges for fish and, at the same time, under equal bottom conditions Macrocystis is probably more important in developing a detritus-based (recycling) food web than as a component of spatial heterogeneity.

The recycling module within the trophic web of the kelp belt at Puerto Toro seems to be a common feature of most coastal macro-algal-dominated habitats, despite their sometimes diverging community organizations (Castilla and Moreno, 1982; Moreno and Sutherland, 1982; Santelices and Ojeda, 1983). Consequently, care must be taken in comparing whole systems (e.g. northern and southern hemisphere kelp communities), since it could be concluded that ecological convergence exists between 2 kelp communities: those with 'key predators' such as the sea otter (Estes and Palmisano, 1974; Simenstad et al., 1978) and those without such predators. In spite of such differences in structure and function, selective factors to which fish populations are subjected are probably comparable and to a certain extent independent of the kelp (e.g. antipredation refuges). Hence, similar evolution of morphological characters and habitat utilization could have taken place, thus explaining the similarity of groups as distant as the nototheniids and hexagrammids.

Acknowledgements. This paper is part of a comprehensive study on the biology and utilization of Macrocystis pyrifera in southern Chile. The work was financed by a Research Grant. agreed upon between the Armada de Chile and the Pontificia Universidad Católica. The manuscript was written under the Project C-77-24 of the Dirección de Investigación of the Universidad Austral de Chile.

We would like to thank our colleages J. C. Castilla and B. Santelices for encouragement, and our diver friends $T$. Larrea, A. Julián, J. C. Castilla and many others 'que donaron sus cuerpos a la ciencia' We are highly indebted to J. A. Estes, E. S. Hobson, C. A. Simenstad, and M. G. White for valuable comments and suggestions. W. Hazen, San Diego State University, provided valuable logistic support.

\section{LITERATURE CITED}

Andersen, N. C., Hureau, J. C. (1979). Proposition pour une nouvelle classification des Nototheniinae (Pisces, Perciformes, Nototheniidae). Cybium 5 (1): 47-53

Boswall, J., Maclver, D. (1975). The magellanic penguin Spheniscus magellanicus. In: Stonehouse, B. (ed.) The biology of penguins. University Park Press, Baltimore, p. 271-305

Burchett, M. S. (1982). The ecology of some coastal fish populations at South Georgia. Prog. Underwater Science, U. K. $7: 15-20$

Castilla, J. C., Moreno, C. A. (1982). Sea urchins and Macrocystis pyrifera: experimental test of their ecological relations in Southern Chile. In: Lawrence, J. M. (ed.) Echinoderms: Proceedings of the International Conference. Tampa Bay, Florida. A. A. Balkema, Rotterdam, p. $257-263$

Daniels, R. A. (1978). Nesting behaviour of Harpagifer bispinis in Arthur Harbour, Antarctic Peninsula. J. Fish. Biol. 12: $465-474$

Dayton, P. K. (1974). Kelp communities in southern South America. Antarctic J. U. S. 9: 22-23

Dayton, P. K. (1975). Experimental studies of algal canopy interaction in a sea-otter dominated kelp community at Amchitka Island, Alaska. Fish. Bull. U. S. 73: 230-237

De Witt, H. H. (1971), Coastal and deep-water, benthic fishes of the Antarctic. In: Bushnell, V. C. (ed.) Antarctic map folio series, Folio 15. American Geographical Society, New York, p. $1-10$

Duggins, D. O. (1980). Kelp beds and sea otters: an experimental approach. Ecology $61: 447-453$

Eastman, J. T., DeVries, A. L. (1982). Buoyancy studies of Notothenioid fishes in McMurdo Sound, Antarctica Copeia 1982 (2): 385-393

Ebeling, A. W., Larson, R. J., Alevizon, W. S., Bray, R. N (1980). Annual variability of reef-fish assemblages in kelp forests off Santa Barbara, California. Fish. Bull. U. S. 78 $361-377$

Estes, J. A., Palmisano, J. F. (1974). Sea otters: their role in structuring nearshore communities. Science, N. Y. 185: 1058-1060

Estes, J. A., Smith, N. S., Palmisano, J. F. (1978). Sea otter predation and community organization in the western Aleutian Islands, Alaska. Ecology 59: 822-833

Foreman, R. E. (1977). Benthic community modification and recovery following intensive grazing by Strongylocentrotus droebachiensis. Helgoländer wiss. Meeresunters. 30: $468-484$

Foster, M. S. (1975a). Algal succession in a Macrocystis pyrifera forest. Mar. Biol. 32: 313-329

Foster, M. S. (1975b). Regulation of algal community development in a Macrocystis pyrifera forest. Mar Biol. 32: $331-342$

Fowler, H. N. (1941). Fishes of Chile. Systematic catalog. Revta chil. Hist. nat. 45: 22-57

Fuentes, H. R. (1981). Feeding habit of Semicossiphus maculatus (Labridae) in coastal waters of Iquique in Northern Chile. Jap. J. Ichthyol. 27 (4): 309-315

Hobson, E. S., Chess, J. R. (1976). Trophic interactions among fishes and zooplankters near shore at Santa Catalina Island, California. Fish. Bull. U. S. $74: 567-598$

Hureau, J. C. (1970). Biologie comparee de quelques poissons antarctiques (Nototheniidae). Bull. Inst. Oceanogr. Monaco 68 (1391): 1-244

Mann, J. H., Breen, P. A. (1971). The relation between lobster abundance, sea urchins, and kelp beds. J. Fish. Res. Bd Can. 29: 603-605 
Moreno, C. A. (1980). Observations on food and reproduction in Trematomus bernacchii (Pisces: Nototheniidae) from. the Palmer Archipelago. Antarctica, Copeia 1980: $171-173$

Moreno, C. A. (1981). Desarrollo de los estudios sobre relaciones tróficas en peces del sublitoral rocoso antártico y subantártico de Chile. Medio Ambiente 5: 161-174

Moreno, C. A., Zamorano, J. H. (1980a). Selección de los alimentos en Notothenia coriiceps neglecta del cinturón de algas de Bahía South. Ser. Cient. Inst. Antárt. Chileno 25: $33-44$

Moreno, C. A., Zamorano, J. H. (1980b). Selectividad del alimento en dos peces bentófagos (Mugiloides chilensis y Calliclinus geniguttatus). Bolm. Inst. Oceanogr., Sao Paulo, Brasil 29 (2): 11-15

Moreno, C. A., Jara, H. F. (1981). Reencuentro de Notothenia trigramma Regan (Pisces: Nototheniidae) en los canales sur Patagónicos, Chile. Not. Men. Mus. Nac. Hist. Nat. 26 (301): $7-9$

Moreno, C. A., Sutherland, J. P. (1982). Physical and biological processes in a Macrocystis pyrifera community near Valdivia, Chile. Oecologia (Berl.) 55: 1-6

Moreno, C. A., Duarte, W. E., Zamorano, J. H. (1979). Variación latitudinal del número de especies de peces en el sublitoral rocoso: una explicación ecológica. Arch. Biol. Med. Exper. 12: 169-178

Morisita, M. (1959). Measuring of interspecific association and similarity between communities. Mem. Fac. Sci. Kyushu Univ. Ser. E. (Biology) 3: 65-80

Navarro, J., Pequeño, G. (1978). Peces litorales de los archipiélagos de Chiloé y los Chonos. Chile. Rev. Biol. Mar. (Chile) 16 (3): 255-309

Neushul, M. (1971). The species of Macrocystis with particular reference to those of North and South America. Nova Hedwigia 32: 211-222

Nelson, J. S. (1976). Fishes of the world. John Wiley \& Sons, New York

North, W J. (1979). Adverse factors affecting giant kelp and associated seaweeds. Experientia 35 (4): 445-447

Pearse, J. S., Hines, A. H. (1979). Expansion of a Central California kelp forest following the mass mortality of sea urchins. Mar. Biol. 51: 83-91
Pickard, G. L. (1971). Some physical oceanographic features of inlets of Chile. J. Fish. Res. Bd Can. 28: 1077-1106

Quast, J. C. (1968). Fish fauna of the rocky inshore zone. Calif. Dept. Fish Game, Fish. Bull. 139: 35-36

Rosenthal, R. J., Clarke, W D., Dayton, P. K. (1974). Ecology and natural history of a stand of giant kelp, Macrocystis pyrifera, off Del Mar, California. Fish. Bull, U. S. 72 : $670-684$

Santelices, B. (1981). Las comunidades de organismos en los bosques de Macrocystis pyrifera en el área del canal Beagle. In: Santelices, B. (ed.) Biología y Factibilidad de Utilización de Praderas de Macrocystis pyrifera en Puerto Toro, Isla Navarino, Chile. Universidad Católica de Chile, Santiago, Chile, p. 129-161

Santelices, B., Ojeda, F. P. (1983). Population dynamics of coastal forests of Macrocystis pyrifera in Puerto Toro, Isla Navarino, Southern Chile. Mar. Ecol. Prog. Ser. 14: $175-183$

Schlatter, R. P., Moreno, C. A. (1976). Hábitos alimentarios del cormorán antártico, Phalacrocorax atriceps bransfieldensis (Murphy) en Isla Green, Antártica. Ser. Cient. Inst. Antárt. Chileno 4 (1): 69-88

Simenstad, C. A., Isakson, J. S., Nakatani, R. E. (1977). Marine fish communities. In: Meritt, M. L., Fullev, R. G. (ed.) The environment of Amchitka Island, Alaska, US. ERDA (Energy Research and Development Administration), Tid26712, p. 451-492

Simenstad, C. A., Estes, J. A., Kenyon, K. W. (1978). Aleuts, sea otters, and alternate stable-state communities. Science, N. Y 200: 403-411

Sokal, R. R., Sneath, P. H. A. (1963). Principles of numerical taxonomy. W.H. Freeman, San Francisco

Sokal, R. R., Rohlf, F. J. (1969). Biometry. W. H. Freeman, San Francisco

Venegas, C., Jory, J. (1979). Guía de campo para las aves de Magallanes. Pub. Inst. Patagonia. Pta. Arenas. Chile

White, M. G., North, A. N., Twelves, E. L., Jones, S. (1982). Early development of Notothenia neglecta from the Scotia Sea, Antarctica. Cybium 6 (1): 43-51

Windell, J. T. (1971). Food analysis and rate of digestion. In: Ricker, W. E. (ed.) Fish production in fresh waters. I.B.P. Handbook 3, p. 215-226 